\title{
DISPLACEMENT-DISPERSIVE LIQUID-LIQUID MICROEXTRACTION BASED ON SOLIDIFICATION FLOATING ORGANIC DROP TRACE AMOUNTS OF LEAD IN WATER SAMPLE PRIOR TO FLAME ATOMIC ABSORPTION SPECTROMETRY DETERMINATION
}

\author{
DARYOUSH AFZALI ${ }^{a}$, MARYAM FAYAZI ${ }^{b}$, ALI MOSTAFAVI ${ }^{b}$ \\ ${ }^{a}$ Environment Department, International Center for Science, High Technology \& Environmental Sciences, Kerman, Iran \\ ${ }^{b}$ Chemistry Department, Shahid Bahonar University of Kerman, Kerman, Iran \\ Young Researchers Society, Shahid Bahonar University of Kerman, Iran \\ (Received: January 27, 2012 - Accepted: October 12, 2012)
}

\begin{abstract}
In this study, a novel method using displacement-dispersive liquid-liquid microextraction based on solidification of floating organic drop in complicated samples prior to flame atomic absorption spectrometry determination was developed. This method involves two consecutive dispersive liquid-liquid microextraction based on solidification. In step I, Zn(II) ions reacted with ammonium pyrrolidine dithio carbamate (APDC) to form Zn-APDC complex and was extracted with the solidified floating organic drop microextraction procedure using 1-undecanol (extraction solvent) and ethanol (dispersive solvent). In step II, after centrifugation and solidification, the separated drop was dissolved in dimethylformamide (DMF) and then dispersed into the sample solution containing lead ion and another dispersive liquid-liquid microextraction based on solidification procedure was carried out. Due to the greater stability of $\mathrm{Pb}-\mathrm{APDC}, \mathrm{Pb}$ displaces $\mathrm{Zn}$ from the preextracted $\mathrm{Zn}-\mathrm{APDC}$ and preconcentration of $\mathrm{Pb}$ was achieved. Under the optimized conditions, the calibration curve was linear in the range of 4-700 $\mathrm{ng} \mathrm{mL}^{-1}$ with detection limit of $0.7 \mathrm{ng} \mathrm{mL}^{-1}\left(3 \sigma_{\mathrm{b}}\right)$. The relative standard deviation of $\pm 1.6 \%$ was obtained $(\mathrm{n}=7)$ and the enrichment factor was found to be 35.0 .
\end{abstract}

Keywords: Displacement extraction; Lead determination; Microextraction; Preconcentration

\section{INTRODUCTION}

Lead is known to be a toxic metal that accumulates in the human body. Its cumulative poisoning effects are serious hematological damage, brain damage, anemia, and kidney malfunctioning. ${ }^{1}$ Allowed concentrations of lead in biological samples are as low as the levels of nanogram per kilogram or nanogram per milliliter. The World Health Organization (WHO) has established provisional tolerable weekly intakes of $\mathrm{Pb}$ of $0.025 \mathrm{mg} \mathrm{kg}^{-1}$ body weight for all human groups. ${ }^{2}$ In 1991, the United States Environmental Protection Agency (EPA) published a regulation to control lead in drinking water, which included an action level of $0.015 \mathrm{mg} \mathrm{L}^{-1}$. $^{3}$ WHO has released guidelines for drinking water quality containing the guideline value of $0.01 \mathrm{mg} \mathrm{L}^{-1}$ for $\mathrm{Pb}^{4}{ }^{4}$ Due to the low concentration of lead and its matrix effects in environmental samples ${ }^{5}$, separation and preconcentration steps are usually required for determination of trace amount of lead. Several procedures such as liquid liquid extraction (LLE), ${ }^{6-9}$ co-precipitation ${ }^{10}$ and solid-phase extraction ${ }^{11-13}$ have been developed for the separation and preconcentration of lead from environmental matrices. Modern trends in analytical chemistry are towards the simplification and miniaturization of sample preparation, as well as the minimization of the organic solvent used. In this regard, several novel microextraction techniques have been developed for reducing the analysis step, increasing the sample throughput and improving the quality and the sensitivity of the analytical methods. Cloud point extraction (CPE), ${ }^{14-16}$ homogeneous liquid-liquid extraction (HLLE), ${ }^{17,} 18$ liquid-phase microextraction (LPME) $)^{19,} 20$ and solid-phase microextraction (SPME) ${ }^{21}$ are some of the newer methods of sample preparation. Recently, Dadfarnia et al. ${ }^{22}$ developed a new liquid-liquid microextraction method based on solidification of floating organic drop, which was successfully used for the separation and preconcentration of lead. Solidified floating organic drop microextraction (SFODME) is a new microextraction technique in which a small volume of an organic solvent with melting point near room temperature (in the range of $10-30{ }^{\circ} \mathrm{C}$ ) is floated on the surface of the aqueous solution. The aqueous phase is stirred for a prescribed period of time and then the sample is transferred into an ice bath. When the organic solvent is solidified, it is transferred into a small conical vial, and the melted organic solvent is used for analyte determination. ${ }^{23}$ SFODME has the advantages of simplicity, low cost, short extraction time, minimum organic solvent consumption and high enrichment factor. ${ }^{24}$ Dispersive liquid-liquid microextraction based on the solidification of floating organic drop (DLLME-SFO) is a combination of DLLME and SFODME in which the extraction solvent with properties similar to that of SFODME is dispersed into the aqueous sample..$^{25}$

In conventional DLLME-SFO for preconcentration of metal ions, the first step is hydrophobic metal-chelate. Obviously, many ligands have little selectivity towards metal ions. In other words, competition for the complexing agent from other co-existing transition metal ions with target analyte cannot be avoided and there may cause undesirable interferences. In fact, all metal-chelate based preconcentration systems have encountered this problem. Adding a masking agent or increasing the concentration of the complexing agent is a choice, but the effectiveness may be marginal and there is the risk of contamination. Recently, Yan et al. have successfully developed a displacement-sorption preconcentration protocol for highly selective quantification of metal ions in complicated matrices. ${ }^{26}$ The principle of this technique is based on the stability difference of metal complexes. The target metal $\left(\mathrm{M}_{1}\right)$ with higher complex stability ( $M_{-}-L, L$ is the ligand) can replace another metal $\left(M_{2}\right)$ with lower complex stability from its complex $\left(\mathrm{M}_{2}-\mathrm{L}\right)$, whereas the reverse reaction cannot occur. Also, throughout the displacement reaction, interferences from the coexisting ions due to the competition for the ligand are largely eliminated. This displacement-sorption preconcentration method has been successfully applied for the determination of mercury in environmental and biological samples, ${ }^{27}$, ${ }^{28}$ methyl mercury in fish samples, ${ }^{29}$ palladium in road dusts ${ }^{30}$ and silver in water samples. ${ }^{31}$ A displacement-cloud point extraction was also developed by employing the same principle and applied for the selective determination of silver. ${ }^{32} \mathrm{~A}$ displacement-dispersive liquid-liquid microextraction coupled with graphite furnace atomic absorption spectrometry has also been developed for the selective determination of silver. ${ }^{33}$

In this work, the displacement reaction principle was employed in solidification of floating organic drop microextraction of metal ions, and displacement-dispersive liquid-liquid microextraction based on solidification of floating organic drop (D-DLLME-SFO) method was developed for the selective separation of lead. In this method, APDC was selected as the chelating agent and $\mathrm{Zn}$ (II) was employed as the pre-extraction metal ion for the best selectivity of displacement. The DLLME-SFO procedure was carried out twice during a single sample pretreatment process: firstly, $\mathrm{Zn}$ (II) was complexed with APDC and subjected to DLLME-SFO process. Then the solidified organic drop from the first DLLME-SFO was transferred into a small conical vial. After dissolving in DMF, it was dispersed into the sample solution containing lead ions and DLLME-SFO process was implemented for the second times. Because the stability of $\mathrm{Pb}$-APDC is greater than that of $\mathrm{Zn}-\mathrm{APDC}, \mathrm{Pb}(\mathrm{II})$ replaces $\mathrm{Zn}(\mathrm{II})$ from the pre-extracted $\mathrm{Zn}$-APDC complex and enters the extraction phase. Then the solidified solvent drop was transferred into a conical vial where it melts and was diluted with ethanol for FAAS determination.

\section{EXPERIMENTAL}

Apparatus

The lead measurements were performed with a Varian SpectrAA 220 flame atomic absorption spectrometer (Australia, http://www.varianinc.com) 
equipped with a computer processor. A lead hollow cathode lamp, operated at $10 \mathrm{~mA}$, was utilized as the radiation source. The analytical wavelength of $283.3 \mathrm{~nm}$ and a slit width $0.5 \mathrm{~nm}$ were used as recommended by manufacturers. A Metrohm $827 \mathrm{pH}$ meter (model 827, Switzerland, www.metrohm.com) was used for $\mathrm{pH}$ measurements with a combined $\mathrm{pH}$ glass electrode calibrated against two standard buffer solutions at $\mathrm{pH} 4.0$ and 7.0. An IEC-model HN-S centrifuge (New York, USA, http://www.gsrtech.com/c/hns-ii.html) was used to accelerate the phase separation.

\section{Reagents and samples}

The reagents used throughout this study were of the highest purity available and at least of analytical reagent grade. The standard stock solutions of lead $\left(100.0 \mu \mathrm{g} \mathrm{mL}^{-1}\right)$ and zinc $\left(100.0 \mu \mathrm{g} \mathrm{mL}^{-1}\right)$ were prepared using lead and zinc from Merck (Darmstadt, Germany). Standard solutions of lead and zinc were prepared daily by appropriate dilution of the stock solutions. 1-undecanol was obtained from Merck and used as extracting solvent. A solution of ammonium pyrrolidine dithio carbamate (APDC, $0.01 \% \mathrm{w} / \mathrm{v}$ ) was prepared every day by dissolving an appropriate amount of APDC (99\%, Merck) in double-distilled water. A solution of $10 \%(\mathrm{w} / \mathrm{v}) \mathrm{NaNO}_{3}$ was prepared by dissolving of 10.0 $\mathrm{g}$ of $\mathrm{NaNO}_{3}$ (Merck) in $100.0 \mathrm{~mL}$ of double-distilled water. All vessels used for trace analysis were kept in a $1 \mathrm{~mol} \mathrm{~L}^{-1} \mathrm{HNO}_{3}$ solution for at least $24 \mathrm{~h}$ and washed twice with double-distilled water before they were used.

\section{General procedure}

$1 \mathrm{~mL}$ of APDC solution and $0.6 \mathrm{~mL}$ of $\mathrm{NaNO}_{3}(10 \%)$ solution were added to $7.0 \mathrm{~mL}$ of $10.0 \mu \mathrm{g} \mathrm{mL}-1 \mathrm{Zn}(\mathrm{II})$ solution. After $\mathrm{pH}$ adjustment at 5.0 , the volume of the sample was raised to $10.0 \mathrm{~mL}$ in a $12 \mathrm{~mL}$ test tube. Then $0.5 \mathrm{~mL}$ of ethanol (dispersive solvent) containing $45.0 \mu \mathrm{L}$ of 1 -undecanol (extraction solvent) was rapidly injected into the sample solution using a 1.0 $\mathrm{mL}$ syringe. A cloudy solution was formed in the test tube and the complex of $\mathrm{Zn}(\mathrm{II})$ with APDC was extracted into fine droplets of 1-undecanol. This turbid solution was then centrifuged for $8 \mathrm{~min}$ at $2500 \mathrm{rpm}$ leading to the aggregation of 1-undecanol as a floating drop on the surface of solution. The tube was now transferred to a beaker containing crushed ice and after $5 \mathrm{~min}$; the solidified solvent drop was transferred to a conical vial where it immediately melted. The melted organic solvent was dissolved in $0.4 \mathrm{~mL}$ DMF and injected into the sample solution containing $0.24 \mathrm{~mL}$ of $10.0 \mu \mathrm{g} \mathrm{mL}^{-1} \mathrm{~Pb}$ (II) solution and $0.4 \mathrm{~mL}$ of $\mathrm{NaNO}_{3}(10 \%)$ solution. In this step, a cloudy solution was formed in which $\mathrm{Pb}$ replaced $\mathrm{Zn}$ from the pre-extracted $\mathrm{Zn}$-APDC complex and entered into the extraction solvent phase. This turbid solution was also centrifuged for 8 min at $2500 \mathrm{rpm}$ and then the tube was transferred to a beaker containing crushed ice. After $5 \mathrm{~min}$, the solidified solvent drop was transferred into a conical vial where it melted and was diluted to $300 \mu \mathrm{L}$ with DMF for FAAS determination.

\section{Sample preparation}

\section{Preparation of water samples}

Tap, rain and spring water samples from the Kerman and Sirjan were collected in acid leached polyethylene vials. Acidification to $\mathrm{pH} 1.0$ with nitric acid was performed immediately after collection, in order to prevent adsorption of the metal ions on the vial walls. The samples were filtered before analyses through a cellulose membrane (Millipore) of $0.45 \mu \mathrm{m}$ pore size.

\section{Preparation of MA-1b standard samples}

An accurately measured sample $(500.0 \mathrm{mg}$ ) of gold ore sample (Canadian Certified Reference Material (MA-1b)) was dissolved completely by heating in a mixture of $\mathrm{HNO}_{3}(\sim 2 \mathrm{~mL}), \mathrm{HCL}(\sim 6 \mathrm{~mL})$ and $\mathrm{HF}(\sim 1 \mathrm{~mL})$. To remove the excess HF the solution was evaporated to near dryness, then cooled, diluted and filtered. The volume of the filtrate was raised to $50.0 \mathrm{~mL}$ with distilled water in a calibrated flask.

\section{RESULTS AND DISCUSSION}

\section{Effect of $\mathrm{pH}$}

The $\mathrm{pH}$ of pre-extraction solution (the acidity of $\mathrm{Zn}$ solution) influences the formation of the Zn-APDC complex, its pre-extraction and subsequent displacement extraction. So the effect of $\mathrm{pH}$ of $\mathrm{Zn}(\mathrm{II})$ solution on the D-DLLME-SFO of $\mathrm{Pb}$ was studied in $\mathrm{pH}$ range of 1.0 to 10.0. As can be seen in Fig. 1, the highest recovery of $\mathrm{Pb}$ extraction was obtained in $\mathrm{pH}$ range of 3.0 to 7.0. Therefore, $\mathrm{pH}$ of 5.0 was selected for further study. The $\mathrm{pH}$ of sample solution influences the stability of Pb-APDC complex and the displacement reaction. Again, the effect of the $\mathrm{pH}$ of sample solution on the extraction recovery of $\mathrm{Pb}$ was investigated in the $\mathrm{pH}$ range 1.5 to 9.5 . The results (Fig. 1) show that the highest recovery was obtained in the $\mathrm{pH}$ range of 3.5 to 7.0 .
Therefore, $\mathrm{pH} 5.5$ was used for the sample solution in the second extraction process.

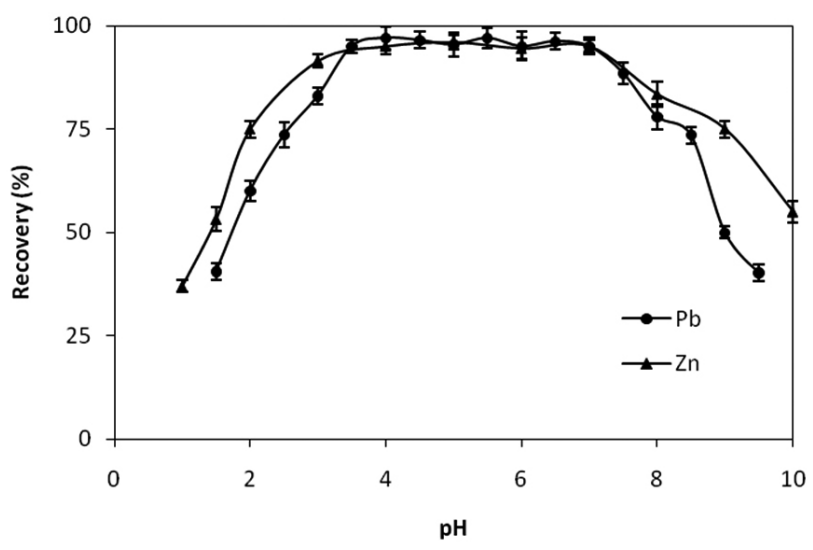

Fig. 1. Effect of $\mathrm{pH}$ on the extraction of $2.4 \mu \mathrm{g}$ of $\mathrm{Pb}$ (II). Extraction conditions step 1: aqueous sample volume, $10 \mathrm{~mL}$; APDC $0.01 \%(\mathrm{w} / \mathrm{v}), 1.0 \mathrm{~mL}$; extracting solvent, 1-undecanol, $45 \mu \mathrm{L}$; dispersive solvent, ethanol, $0.5 \mathrm{~mL}$; amount of $\mathrm{Zn}, 7.0 \mathrm{~mL}$; volume of $\mathrm{NaNO}_{3} 10 \%(\mathrm{w} / \mathrm{v}), 0.6 \mathrm{~mL}$; centrifugation time, $8 \mathrm{~min}$; Extraction conditions step 2, dispersive solvent, DMF, $0.4 \mathrm{~mL}$; volume of $\mathrm{NaNO}_{3} 10 \%(\mathrm{w} / \mathrm{v}), 0.4 \mathrm{~mL}$.

\section{Effect of APDC amount}

To examine the effect of ligand amount, different volumes of $0.01 \%(\mathrm{w} / \mathrm{v})$ APDC solution $(0.4-1.3 \mathrm{~mL}$ ) were investigated. Recovery of $\mathrm{Pb}$ increases with an increase in APDC volume up to $1.0 \mathrm{~mL}$ and then remains constant. Accordingly, $1.0 \mathrm{~mL}$ of $0.01 \%(\mathrm{w} / \mathrm{v})$ APDC solution was chosen as optimal volume for subsequent experiments.

\section{Effect of Zn amount}

$\mathrm{Zn}$ amount influences the amount of pre-extracted $\mathrm{Zn}-\mathrm{APDC}$ and the subsequent displacement reaction. Different volumes of $10.0 \mu \mathrm{g} \mathrm{mL}^{-1} \mathrm{Zn}$ solution were used in the first DLLME-SFO procedure and their effects on the extraction of $\mathrm{Pb}$ (the second DLLME-SFO procedure) were evaluated. Studies on the effect of $\mathrm{Zn}$ amount showed that the extraction recovery of $\mathrm{Pb}$ increased with the increase of $\mathrm{Zn}$ volume up to $7.0 \mathrm{~mL}$ and remained unchanged with further increase in $\mathrm{Zn}$ volume. For further experiments, a volume of $7.0 \mathrm{~mL}$ was used.

\section{Selection of extracting solvent}

The extracting solvent for DLLME-SFO should be able to form a cloudy solution in the aqueous phase. In addition, it must have a lower density than water, high extraction capability for the compounds of interest, low volatility, low water solubility and a melting point near room temperature. ${ }^{34}$ Several extracting solvents, including 1-undecanol $\left(\mathrm{mp} 13-15{ }^{\circ} \mathrm{C}\right)$, 1-hexadecanethiol $\left(\mathrm{mp} 18-20^{\circ} \mathrm{C}\right.$ ) and 2 -undecanone $\left(\mathrm{mp} 11-13^{\circ} \mathrm{C}\right.$ ) were investigated. 1-undecanol was selected because higher extraction efficiency, sensitivity, stability, lower price, low water solubility and low vapor pressure.

\section{Effect of extraction solvent volume}

In order to study the effect of the volume of the extraction solvent on the extraction efficiency, different volumes of 1-undecanol $(20.0-60.0 \mu \mathrm{L})$ dissolved in a constant volume of dispersive solvent (ethanol, $0.5 \mathrm{~mL}$ ) were tested. Extraction recovery increased with the increase of 1-undecanol volume up to $45 \mu \mathrm{L}$ and then remained constant. Therefore, $45 \mu \mathrm{L}$ of 1-undedanol was used as the extraction solvent in subsequent experiments.

\section{Selection of disperser solvent}

The miscibility of the disperser solvent in the organic phase (extracting solvent) and the aqueous phase (sample solution) is the main criterion for the selection of a disperser solvent. Several disperser solvents, including ethanol, acetonitrile, methanol and acetone were investigated for the first DLLMESFO process. The effect of these dispersers on the extraction efficiency of D-DLLME-SFO of $\mathrm{Pb}$ was studied using $0.5 \mathrm{~mL}$ of each solvent containing $45.0 \mu \mathrm{L}$ of 1 -undedanol as the extraction solvent. The highest recoveries were obtained with ethanol; hence ethanol was selected as the optimal disperser 
solvent in this process. For the second extraction process, ethanol, DMF, DMSO and acetone were used to dilute the separated drop from previous step and disperse it into $\mathrm{Pb}(\mathrm{II})$ solution. Since the highest recovery was obtained with DMF, it was selected as the optimal disperser solvent for further studies in second extraction process.

Effect of volume of the disperser solvent

After the selection of dispersive solvents for the first and second extraction processes, their volumes were also optimized. For this purpose, different volumes of ethanol in the range $0.2-0.9 \mathrm{~mL}$ containing $45.0 \mu \mathrm{L}$ of 1 -undecanol (as the extracting solvent) were used for the extraction of $\mathrm{Pb}$ ions using the D-DLLME-SFO procedure. The highest extraction recovery was obtained in the range of 0.4 to $0.6 \mathrm{~mL}$. Therefore, $0.5 \mathrm{~mL}$ ethanol was selected for further study. In the second extraction process, the separated phase of the first extraction process was dispersed into the sample solution using DMF as the dispersive solvent. The effect of the volume of DMF on the recovery of $\mathrm{Pb}$ extraction was studied. The highest recovery was obtained in the range of 0.3 to $0.5 \mathrm{~mL}$. Therefore, $0.4 \mathrm{~mL}$ DMF was selected.

\section{Effect of salt addition}

Depending on the nature of the target analytes, addition of salt to the sample solution can decrease their solubility and therefore enhance extraction efficiency due to the salting-out effect. Salting-out is a process of addition of electrolytes to an aqueous phase in order to increase the distribution ratio of a particular solute. The term also connotes reduction of mutual miscibility of two liquids by addition of electrolytes. ${ }^{35}$ The effect of salt on extraction efficiency was studied by varying the volume of $\mathrm{NaNO}_{3}$ solution $(10 \%, \mathrm{w} / \mathrm{v})$ in the range of $0.1-1.0 \mathrm{~mL}$. The results show that the highest extraction recovery was obtained in the presence of 0.6 and $0.4 \mathrm{~mL}$ of $\mathrm{NaNO}_{3}$ solution for the first and second extraction processes, respectively.

\section{Effect of centrifugation time}

Centrifugation was necessary to obtain two distinguishable phases in the extraction tubes. The effect of centrifugation time on the extraction efficiency was evaluated in the range of 4-14 min at $2500 \mathrm{rpm}$. The extraction performance reached its peak when the solution was centrifuged at $2500 \mathrm{rmp}$ for $8 \mathrm{~min}$. When the centrifugation time was longer than $8 \mathrm{~min}$, the extraction recovery remained constant, so 8 min was chosen in the following study.

Effects of co-existing ions

In the conventional DLLME-SFO procedure, ${ }^{36}$ most interference was the result of the competition of other heavy metal ions for the chelating agent and their subsequent co-extraction with the analyte. With the introduction of displacement reaction, the selectivity of displacement sorption preconcentration and displacement-cloud point extraction was largely improved. The same effect was also expected in D-DLLME-SFO method. The effects of several potentially interfering species were carefully studied. The corresponding results are compared in Table 1. Compared with the conventional DLLMESFO method, the D-DLLME-SFO method shows an improvement in the tolerance limits of co-existing heavy metal ions. The high selectivity of the developed D-DLLME-SFO method for the determination of trace amounts $\mathrm{Pb}$ (II) is also clearly demonstrated.

\section{Analytical figures of merit}

The analytical figures of merit were evaluated for the determination of $\mathrm{Pb}$ (II) according to the recommended procedure under optimized conditions. Under optimal conditions, the calibration curve was linear from 4.0 to $700 \mathrm{ng}$ $\mathrm{mL}^{-1}$ in the initial solution with a correlation coefficient of $0.9987\left(R^{2}\right)$. The recommended procedure was repeated seven times for the determination of $240 \mathrm{ng} \mathrm{mL}^{-1}$ of $\mathrm{Pb}$ ion to obtain the relative standard deviation which was found to be $\pm 1.6 \%$. The enrichment factor was 35.0 (enrichment factor $(E F)=M_{a} /$ $M_{b}$, where $M_{a}$ and $M_{b}$ are respectively the slopes of the curves after and before preconcentration. The limit of detection, calculated as $3 \sigma_{\mathrm{b}}\left(\sigma_{\mathrm{b}}\right.$ is the standard deviation of the blank), was $0.7 \mathrm{ng} \mathrm{mL}^{-1}$.

\section{Application of the method}

Application to real sample

To test the reliability of the recommended procedure, the method was applied to the determination of lead in tap, river, rain and spring water samples. For this purpose, a volume of $10.0 \mathrm{~mL}$ of each sample were preconcentrated with $45.0 \mu \mathrm{L}$ of 1-undecanol according to the proposed method. The lead amounts in water samples are tabulated in Table 2.
Table 1 .Tolerance limits of co-existing ion.

\begin{tabular}{|c|c|c|}
\hline Ion & Tolerance limits $\left(\mu \mathrm{g} \mathrm{mL}^{-1}\right)$ & \\
\hline $\mathrm{Mn}^{2+}$ & 2000 & $\begin{array}{c}\text { Conventional } \\
\text { DLLME-SFO }\end{array}$ \\
\hline $\mathrm{Mg}^{2+}$ & 5000 & 500 \\
\hline $\mathrm{Co}^{2+}$ & 1000 & 4000 \\
\hline $\mathrm{Ca}^{2+}$ & 5500 & - \\
\hline $\mathrm{Al}^{3+}$ & 1000 & 4000 \\
\hline $\mathrm{Fe}^{3+}$ & 1500 & 500 \\
\hline $\mathrm{Cr}^{3+}$ & 600 & 500 \\
\hline $\mathrm{Bi}^{3+}$ & 1400 & - \\
\hline $\mathrm{Ni}^{2+}$ & 800 & - \\
\hline $\mathrm{Zn}^{2+}$ & 3000 & 2000 \\
\hline $\mathrm{Cd}^{2+}$ & 3800 & 2000 \\
\hline $\mathrm{Cu}^{2+}$ & 4000 & 2000 \\
\hline $\mathrm{Br}^{-}$ & 1800 & - \\
\hline $\mathrm{I}$ & 1700 & - \\
\hline
\end{tabular}

a APDC as complexing agent

b2-(5-bromo-2-pyridylazo)-5-(diethyl amino) phenol (5-Br PADAP) as complexing agent

Table 2. Determination of $\mathrm{Pb}$ (II) in water samples.

\begin{tabular}{|l|c|}
\hline Sample & Found $\left(\mu \mathrm{g} \mathrm{L}^{-1}\right)^{\mathrm{a}}$ \\
\hline Rain water (Kerman) & $4.68 \pm 0.08$ \\
\hline Rain water (Sirjan) & B.L.R ${ }^{\mathrm{b}}$ \\
\hline Tap water (Kerman) & $5.20 \pm 0.07$ \\
\hline Tap water (Sirjan) & $5.83 \pm 0.09$ \\
\hline Spring water (Sirjan) & $4.10 \pm 0.06$ \\
\hline Spring water (Kerman) & B.L.R \\
\hline River water (Mahan, Kerman) & $4.31 \pm 0.07$ \\
\hline River water (Tangoyeh, Sirjan) & B.L.R \\
\hline
\end{tabular}

${ }^{a}$ Mean $\pm \mathrm{SD}, \mathrm{n}=3$.

${ }^{\mathrm{b}}$ B.L.R: Below of linear range

Analysis of $\mathrm{Pb}$ in a MA-1b standard sample

The method was applied for the determination of $\mathrm{Pb}$ in Canadian Certified Reference Material (MA-1b) Project. An aliquot of this solution was taken and $\mathrm{Pb}$ was determined by the general procedure. Collective results, given in Table 3 indicate the applicability and accuracy of the D-DLLME-SFO method.

Table 3. Determination of lead ions in the Canadian Certified Reference Material.

\begin{tabular}{|c|c|c|c|}
\hline Sample & Composition ( $\%$ or $\mu \mathrm{g} \mathrm{g}^{-1}$ ) & $\begin{array}{l}\text { Found a } \\
\left(\mu \mathrm{g} \mathrm{g}^{-1}\right)\end{array}$ & $\begin{array}{c}\text { Recovery } \\
\text { (\%) }\end{array}$ \\
\hline $\begin{array}{l}\text { MA-1b } \\
\text { reference } \\
\text { gold ore }\end{array}$ & $\begin{array}{l}\mathrm{Si} ; 24.5, \mathrm{Al} ; 6.11, \mathrm{Fe} ; 4.62 \\
\mathrm{Ca} ; 4.60, \mathrm{~K} ; 4.45, \mathrm{Mg} ; 2.56 \\
\mathrm{C} ; 2.44, \mathrm{Na} ; 1.49, \mathrm{~S} ; 1.17, \mathrm{Ti} \\
0.38, \mathrm{Ba} ; 0.18, \mathrm{P} ; 0.16, \mathrm{Mn} \\
0.09 \%, \mathrm{Cr} ; 200.0, \mathrm{~Pb} ; \mathbf{2 0 0 . 0} \\
\mathrm{Rb} ; 160.0, \mathrm{Zr} ; 140.0, \mathrm{Cu} \\
\text { 100.0, Zn; } 100.0, \mathrm{Bi} ; 100.0 \\
\mathrm{Ni} \text {; } 9.0, \mathrm{Mo} ; 80.0, \mathrm{Te} ; 40.0 \\
\mathrm{Co} ; 30.0, \mathrm{Y} ; 20.0, \mathrm{~W} ; 15.0 \\
\mathrm{Sc} ; 13.0, \mathrm{As} ; 8.0, \mathrm{Ag}, 3.9, \mathrm{Sb} \\
\text { 3.0, Au; } 17.0 \mu \mathrm{g} \mathrm{g}^{-1}\end{array}$ & $196.8 \pm 2.2$ & 98.4 \\
\hline
\end{tabular}

${ }^{a}$ Mean \pm SD, $n=3$. 
Comparison with other methods

Determination of lead in aqueous samples by the developed displacementdispersive liquid-liquid microextraction based on solidification was compared with the other preconcentration methods used for determination of lead by flame atomic absorption spectrometry (FAAS). It is obvious from Table 4, the limit of detection (LOD) and relative standard deviation (RSD) of D-DLLMESFO is lower than co-precipitation-FAAS, ${ }^{10}$ off-line-SPE-FAAS, ${ }^{37}$ on-lineSPE-FAAS, ${ }^{11}$ CPE-FAAS, ${ }^{16}$ SPE-FAAS ${ }^{38}$ and SPE-FAAS. ${ }^{39}$ Moreover, this method has higher enrichment factor compared with off-line-SPE-FAAS, ${ }^{37}$ SPE-FAAS ${ }^{11}$ and CPE-FAAS. ${ }^{40}$

Table 4.Comparison of the D-DLLME-SFO with other methods for preconcentration and determination of Pb.

\begin{tabular}{|c|c|c|c|c|c|}
\hline $\begin{array}{l}\text { Preconcentration/ } \\
\text { determination method a }\end{array}$ & $\begin{array}{l}\text { Enrichment } \\
\text { factor }\end{array}$ & $\operatorname{LOD}\left(\mathrm{ng} \mathrm{mL}^{-1}\right)$ & RSD (\%) & $\begin{array}{l}\text { Linear range } \\
\left(\mathrm{ng} \mathrm{mL}^{-1}\right)\end{array}$ & Ref. \\
\hline Co-precipitation & 125 & 16 & 3.0 & - & {$[10]$} \\
\hline On-line-SPE & 330 & 0.8 & 2.6 & $1.6-100$ & [11] \\
\hline $\mathrm{CPE}$ & 50 & 1.1 & $3.51 \mathrm{q}$ & $1.1-160$ & [16] \\
\hline Off-line-SPE & 30 & 6.1 & 4.7 & - & {$[37]$} \\
\hline SPE & 20 & 3.7 & 7 & - & {$[38]$} \\
\hline SPE & 250 & 3.2 & 5.1 & $10.0-300$ & [39] \\
\hline $\mathrm{CPE}$ & 15.1 & 4.5 & 1.6 & $25.0-2000$ & {$[40]$} \\
\hline D-DLLME-SFO & 35.0 & 0.7 & 1.6 & $4.0-700$ & This work \\
\hline
\end{tabular}

${ }^{a}$ Determination system: flame atomic absorption spectrometry

${ }^{\mathrm{b}}$ SPE: Solid phase extraction.

\section{CONCLUSION}

The proposed D-DLLME-SFO coupled with FAAS was successfully used for pre-concentration and determination of $\mathrm{Pb}(\mathrm{II})$ in complicated samples. The new method provides some operational advantages such as simplicity of experimental procedure, low cost, rejection of matrix constituent, enhancement of sensitivity and low organic solvent usage for routine trace $\mathrm{Pb}$ ion analysis. The interference from co-existing heavy metal ions is minimized effectively without the need of any masking reagents. The extraction solvent (1-undecanol) of this method has lower toxicity than DLLME, and thus this method is more environmental friendly.

\section{REFERENCES}

1. Wuilloud, R.G.; Salonia, J.A.; Gasquez, J.A.; Olsina, R.A.; Martinez, L.D.; Anal. Sci. 2001, 17, 457.

2. S.E. Manahan, Environmental Chemistry, CRC Press, Boca Raton, FL, 1994.

3. World Health Organization, Fifty-third Report of the Joint FAO/WHO Expert Committee on Food Additives, WHO Technical Report Series 896, Geneva, Switzerland, 2000

4. United States Environmental Protection Agency, Lead and Copper Rule (LCR) 56 FR 199126460.

5. Camel, V.; Spectrochim. Acta Part B 2003, 58, 1177.

6. Zendelovska, D.; Pavlovsk, G.; Cundeva, K.; Stafilov, T.; Talanta 2001 , $54,139$.

7. Ikeda, K.; Abe, S.; Anal. Chim. Acta 1998, 363, 165.

8. Dapaah, A.R.K.; Takano, N.; Ayame, A.; Anal. Chim. Acta 1999, 386, 281.

9. Komjarova, I.; Blust, R.; Anal. Chim. Acta 2006, 576, 221.

10. Doner, G.; Ege, A.; Anal. Chim. Acta 2005, 547, 14.

11. Zachariadis, G.A.; Anthemidis, A.N.; Bettas, P.G.; Stratis, J.A.; Talanta 2002, 57, 919.

12. Anthemidis, A.N.; Ioannou, K.G.; Anal. Chim. Acta 2006, 575, 126.

13. Barbosa, A.F.; Segatelli, M.G.; Pereira, A.C.; Santos, A.S.; Kubota, L.T.; Luccas, P.O.; Tarley, C.R.T.; Talanta 2007, 71, 1512.

14. Maranhao, T.A.; Borges, D.L.G.; Veigab, M.S.; Curtius, A.J; Spectrochim. Acta Part B 2005, 60, 667

15. Luconi, M.O.; Silva, M.F.; Olsina, R.A.; Fernandez, L.P.; Talanta 2000, 51,123

16. Chen, J.; Teo, K.C.; Anal. Chim. Acta 2001, 450, 215.

17. Chen, J.; Xiao, S.; Wu, X.; Fang, K.; Liu, W.; Talanta 2005, 67, 992.

18. Ebrahimzadeh, H.; Yamini, Y.; Kamare, F.; Shariati, S.; Anal. Chim. Acta 2007, 549, 93.
19. Psillakis, E.; Kalogerakis, N.; Trends Anal. Chem. 2003, 22, 565.

20. Ahmadi, F.; Assadi, Y.; Milani, M.R.; Rezaee, M.; J. Chromatogr. A 2006, $1101,307$.

21. Djozan,D.; Assadi, Y.; Chromatographia 2004, 60, 313.

22. Dadfarnia, S.; Salmanzadeh, A.M.; Shabani, A.M.H.; Anal. Chim. Acta 2008, 623, 163.

23. Dadfarnia, S.; Shabani, A.M.H.; Kamranzadeh, E.; Talanta 2009, 79, 1061.

24. Bidabadi, M.S.; Dadfarnia, S.; Shabani, A.M.H.; J. Hazard. Mater. 2009, 166, 291

25. Khalili-Zanjani, M.R.; Yamini, Y.; Shariati, S.; Jonsson, J.A.; Anal. Chim. Acta 2007, 585, 286.

26. Yan, X.P.; Li, Y.; Jiang, Y.; J. Anal. Atom. Spectrom. 2002, 17, 610.

27. Li, Y.; Jiang, Y.; Yan, X.P.; Ni, Z.M.; Environ. Sci. Technol. 2002, 36, 4886.

28. Dong, L.M.; Yan, X.P.; Li, Y.; Jiang, Y.; Wang, S.W.; Jiang, D.Q.; J. Chromatogr. A 2004, 1036, 119.

29. Yan, X.P.; Li, Y.; Jiang, Y.; Anal. Chem. 2003, 75, 2251.

30. Fang, J.; Jiang, Y.; Yan, X.P.; Ni, Z.M.; Environ. Sci. Technol. 2005, 39, 288.

31. Christou, C.K.; Anthemidis, A.N.; Talanta 2009, 78, 144.

32. Wu, P.; Gao, Y.; Cheng, G.L.; Yang, W.S.; Lv, Y.; Hou, X.D.; J. Anal. Atom. Spectrom. 2008, 23, 752 .

33. Liang, P.; Zhang, L.; Zhao, E.; Talanta 2010, 82, 993.

34. Mohamadi, M.; Mostafavi, A.; Talanta 2010, 81, 309

35. Gupta, M.; Jain, A.; Verma, K.K.; Talanta 2009, 80, 526.

36. Mirzaei, M.; Behzadi, M.; Mahmoud Abadi, N.; Beizaei, A.; J. Hazard. Mater. 2011, 186, 1739.

37. Matoso, E.; Kubota, L.T.; Cadore, S.; Talanta 2003, 60, 1105.

38. Soylak, M.; Narin, I.; Bezerra, M.A.; Ferreira, S.L.C.; Talanta 2005, 65, 895.

39. Parham, H.; Pourreza, N.; Rahbar, N.; J. Hazard. Mater. 2009, 163, 588.

40. Silva, E.L.; Santos Roldan, P.; J. Hazard. Mater. 2009, 161, 142. 